\begin{tabular}{|c|c|c|c|c|c|c|c|c|c|}
\hline \multicolumn{2}{|l|}{ as of coner } & Age (years) & $\begin{array}{l}\begin{array}{l}\text { Gender } \\
\text { (Male) }\end{array} \\
\end{array}$ & $\begin{array}{c}\text { Educational } \\
\text { Level } \\
\text { (University) }\end{array}$ & $\begin{array}{c}\text { Marital } \\
\text { staus } \\
\text { (Married) }\end{array}$ & $\begin{array}{l}\text { BASDAI } \\
(0-10)\end{array}$ & $\begin{array}{c}\text { Stiffness } \\
\text { index } \\
(3-12)\end{array}$ & $\begin{array}{c}\text { Global } \\
\text { Limitition } \\
(0.54)\end{array}$ & $\begin{array}{c}\text { GHQ-12 } \\
(0.12)\end{array}$ \\
\hline \multirow{3}{*}{$\begin{array}{l}\text { Disease } \\
\text { progression } \\
\text { (mean } \pm \text { SD or \%) }\end{array}$} & Yes & $42.4 \pm 11.6$ & $25.9 \%$ & $47.4 \%$ & $64.0 \%$ & $5.7 \pm 1.8$ & $8.6 \pm 2.3$ & $17.7 \pm 12.0$ & $4.5 \pm 4.0$ \\
\hline & No & $44.0 \pm 13.1$ & $41.3 \%$ & $54.0 \%$ & $68.3 \%$ & $5.3 \pm 2.1$ & $7.3 \pm 2.4$ & $12.3 \pm 11.2$ & $5.4 \pm 4.0$ \\
\hline & p-value & $0.016^{*}$ & $<0.001^{*}$ & $<0.001^{*}$ & $0.010^{*}$ & $<0.001^{\circ}$ & $<0.001^{\circ}$ & $<0.001^{*}$ & $<0.001^{*}$ \\
\hline \multirow{3}{*}{$\begin{array}{l}\text { Suffering pain } \\
\text { (mean } \pm \text { SD or \%) }\end{array}$} & Yes & $41.7 \pm 11.5$ & $21.9 \%$ & $48.8 \%$ & $64.3 \%$ & $6.0 \pm 1.7$ & $8.8 \pm 2.2$ & $18.6 \pm 12.4$ & $5.9 \pm 4.1$ \\
\hline & No & $44.2 \pm 13.1$ & $42.2 \%$ & $53.0 \%$ & $67.9 \%$ & $5.2 \pm 2.1$ & $7.3 \pm 2.4$ & $12.3 \pm 10.9$ & $4.3 \pm 3.9$ \\
\hline & p-value & $<0.001^{*}$ & $<0.001^{*}$ & $<0.001^{*}$ & 0.105 & $<0.001^{\circ}$ & $<0.001^{\circ}$ & $<0.001^{*}$ & $<0.001^{*}$ \\
\hline \multirow{3}{*}{$\begin{array}{l}\text { Stiffness } \\
\text { (mean } \pm \text { SD or \%) }\end{array}$} & Yes & $42.1 \pm 12.3$ & $20.9 \%$ & $47.5 \%$ & $65.4 \%$ & $5.9 \pm 1.7$ & $9.1 \pm 2.0$ & $18.8 \pm 12.2$ & $5.8 \pm 4.1$ \\
\hline & No & $43.7 \pm 12.7$ & $39.5 \%$ & $52.7 \%$ & $67.1 \%$ & $5.3 \pm 2.0$ & $7.5 \pm 2.4$ & $13.1 \pm 11.4$ & $4.5 \pm 4.0$ \\
\hline & p-value & & $<0.00$ & 0.097 & & & & $<0.001^{*}$ & $11^{*}$ \\
\hline \multirow{3}{*}{$\begin{array}{l}\text { Loss of mobility } \\
\text { (mean } \pm \text { SD or \%) }\end{array}$} & Yes & $42.2 \pm 11.4$ & 23.9 & & & 1.8 & 2.2 & $18.6 \pm 12.6$ & $8 \pm 4.1$ \\
\hline & No & $43.9 \pm 13.1$ & $41.1 \%$ & $52.3 \%$ & $67.6 \%$ & $5.2 \pm 2.0$ & $7.3 \pm 2.4$ & $12.3 \pm 10.8$ & $4.3 \pm 4.0$ \\
\hline & p-value & $0.010^{\circ}$ & $<0.001^{*}$ & $0.002^{*}$ & 0.281 & $<0.001^{\circ}$ & $<0.001^{\circ}$ & $<0.001^{*}$ & $<0.001^{\circ}$ \\
\hline \multirow{3}{*}{$\begin{array}{l}\text { Loss of } \\
\text { independence/ } \\
\text { disability } \\
\text { (mean } \pm \text { SD or \%) }\end{array}$} & Yes & $42.0 \pm 11.2$ & $22.4 \%$ & $49.7 \%$ & $63.8 \%$ & $5.0 \pm 1.7$ & $8.8 \pm 2.2$ & $19.7 \pm 12.2$ & $6.2 \pm 4.0$ \\
\hline & No & $43.9 \pm 13.1$ & $41.1 \%$ & $52.4 \%$ & $68.0 \%$ & $5.2 \pm 2.1$ & $7.4 \pm 2.4$ & $12.1 \pm 10.9$ & $4.2 \pm 3.9$ \\
\hline & p-value & $0.005^{*}$ & $<0.001^{*}$ & $80.001^{*}$ & $0.036^{*}$ & $<0.001^{\circ}$ & $<0.001^{\circ}$ & $<0.001^{*}$ & $<0.001^{*}$ \\
\hline \multirow{3}{*}{$\begin{array}{l}\text { Social isolation } \\
\text { (friends, } \\
\text { family) } \\
\text { (mean } \pm \text { SD or \%) }\end{array}$} & Yes & $40.2 \pm 10.3$ & $17.8 \%$ & $49.7 \%$ & $56.9 \%$ & $6.2 \pm 1.6$ & $9.3 \pm 2.0$ & $21.3 \pm 12.0$ & $7.2 \pm 4.0$ \\
\hline & No & $43.9+12.9$ & $38.8 \%$ & $52.0 \%$ & $68.4 \%$ & $5.3+2.0$ & $7.6 \pm 2.4$ & $13.1 \pm 11.3$ & $4.4+3.9$ \\
\hline & p-value & $<0.001^{*}$ & $<0.001^{*}$ & $0.031^{*}$ & $<0.001^{*}$ & $<0.001^{\circ}$ & $<0.001^{\circ}$ & $0.001^{*}$ & $<0.001^{*}$ \\
\hline \multirow{3}{*}{$\begin{array}{l}\text { Loss of job/ } \\
\text { inability to work } \\
\text { (mean } \pm \text { SD or \%) }\end{array}$} & Yes & $39.8 \pm 9.6$ & $20.6 \%$ & $50.6 \%$ & $61.7 \%$ & $5.9 \pm 1.8$ & $8.8 \pm 2.1$ & $18.1+11.6$ & $6.2 \pm 4.0$ \\
\hline & No & $44.6 \pm 13.3$ & $41.0 \%$ & $52.0 \%$ & $68.5 \%$ & $5.3 \pm 2.1$ & $7.5 \pm 2.5$ & $13.0 \pm 11.5$ & $4.3+3.9$ \\
\hline & p-value & $60.001^{*}$ & $<0.001^{*}$ & $<0.001^{*}$ & $0.005^{*}$ & $<0.001^{\circ}$ & $<0.001^{\circ}$ & $.001^{*}$ & $<0.001^{*}$ \\
\hline \multirow{3}{*}{$\begin{array}{l}\text { Complications } \\
\text { during a } \\
\text { pregnancy/infertil } \\
\text { ity }\end{array}$} & Yes & $30.1 \pm 5.8$ & $2.6 \%$ & $66.7 \%$ & $50.9 \%$ & $5.4 \pm 2.0$ & $8.3 \pm 2.6$ & $20.4 \pm 12.6$ & $5.9 \pm 3.8$ \\
\hline & No & $44.1 \pm 12.5$ & $37.7 \%$ & $50.8 \%$ & $67.7 \%$ & $5.4 \pm 2.0$ & $7.8 \pm 2.4$ & $13.9 \pm 11.6$ & $4.7 \pm 4.1$ \\
\hline & p-value & $<0.001^{*}$ & $<0.001^{*}$ & $<0.001^{*}$ & $<0.001^{*}$ & 0.747 & $0.017^{*}$ & $<0.001^{*}$ & $0.001^{*}$ \\
\hline \multirow{3}{*}{$\begin{array}{l}\text { Impact of the } \\
\text { disease on my } \\
\text { everyday } \\
\text { activities }\end{array}$} & Yes & & $18.1 \%$ & $49.3 \%$ & 64. & .7 & $8.9 \pm 2.2$ & $19.2 \pm 11.8$ & $6.2 \pm 4.0$ \\
\hline & No & $44.2 \pm 13.0$ & $41.8 \%$ & $52.5 \%$ & $67.5 \%$ & $5.3 \pm 2.1$ & $7.4 \pm 2.4$ & $12.6 \pm 11.3$ & $4.3 \pm 3.9$ \\
\hline & $\begin{array}{l}\text { p-value } \\
\text { plat }\end{array}$ & $<0.001^{*}$ & $<0.001^{*}$ & $0.007^{*}$ & 0.172 & $<0.001^{\circ}$ & $<0.001^{\circ}$ & $<0.001^{*}$ & $<0.001^{*}$ \\
\hline
\end{tabular}

Table 2. Association between patients' hopes and sociodemographic and disease outcomes ( $N: 2166)$

\begin{tabular}{|c|c|c|c|c|c|c|c|c|c|}
\hline \multicolumn{2}{|c|}{ Areas of concern } & (vears) & \begin{tabular}{|l|}
$\begin{array}{l}\text { Gender } \\
\text { (Male) }\end{array}$ \\
\end{tabular} & $\begin{array}{l}\text { Educational } \\
\text { Level }\end{array}$ & $\begin{array}{l}\text { Marital } \\
\text { Status }\end{array}$ & $\begin{array}{l}\text { BASDAI } \\
(0-10)\end{array}$ & $\begin{array}{l}\text { Stiffness } \\
\text { index }\end{array}$ & $\begin{array}{c}\text { Global } \\
\text { Umitation }\end{array}$ & $\begin{array}{l}\text { GHO-12 } \\
(0-12)\end{array}$ \\
\hline \multirow{3}{*}{$\begin{array}{l}\text { To stop disease } \\
\text { progression } \\
\text { (mean } \pm S D \text { or \%) }\end{array}$} & Yes & & $27.0 \%$ & $53.6 \%$ & $63.8 \%$ & $5.5 \pm 2.0$ & $3 \pm 2.4$ & & 444.1 \\
\hline & No & \pm 12.9 & $40.2 \%$ & $0.8 \%$ & $3.3 \%$ & $4 \pm 2.0$ & $.6 \pm 2.4$ & $13.3 \pm 11.5$ & $4.5 \pm 4.0$ \\
\hline & p-value & 0.486 & $<0.001^{\circ}$ & 0.198 & .145 & 0.429 & $.001^{\circ}$ & $60.001^{*}$ & $60.001^{\circ}$ \\
\hline \multirow{3}{*}{$\begin{array}{l}\text { To be treated/ } \\
\text { cured } \\
\text { (mean } \pm \text { SD or } \% \text { ) }\end{array}$} & Yes & \pm 11.7 & $31.2 \%$ & $5 \%$ & $9 \%$ & $6 \pm 2.0$ & $4 \pm 2.5$ & $16.5 \pm 11.9$ & $5.4 \pm 4.0$ \\
\hline & No & & & & & & 2.4 & & $4.6 \pm 4.0$ \\
\hline & p-value & $0.000^{\circ}$ & 0.026 & $0.008^{\circ}$ & 0.0 & • & $.001^{*}$ & $.001^{*}$ & $<0.001^{\circ}$ \\
\hline \multirow{3}{*}{$\begin{array}{l}\text { To eliminate pain } \\
\text { (mean } \pm S D \text { or } \% \text { ) }\end{array}$} & Ye & & $24.2 \%$ & & & & .2 & & 4.0 \\
\hline & No & 0 & & & & & & & \\
\hline & p-value & & $<0.00$ & & 127 & 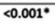 & $11^{\circ}$ & $0.001^{*}$ & 0.00 \\
\hline \multirow{3}{*}{$\begin{array}{l}\text { To improve my } \\
\text { quality of life } \\
\text { (mean } \leftleftarrows \mathrm{SD} \text { or } \% \text { ) }\end{array}$} & Ye & $42.0 \pm 11.7$ & $21.2 \%$ & 50.19 & 64. & $5.9 \pm 1.7$ & $0 \pm 2.1$ & $18.7 \pm 11.6$ & $5.6 \pm 4.1$ \\
\hline & No & $8 \pm 12.9$ & $40.2 \%$ & $1 \%$ & $7.5 \%$ & $3 \pm 2.1$ & $7.5 \pm 2.4$ & $12.9 \pm 11.5$ & $4.6 \pm 4.0$ \\
\hline & p-value & $0.008^{*}$ & $<0.001^{\circ}$ & 0.001 & 0.20 & $<0.001^{\circ}$ & $<0.001^{\circ}$ & $<0.001^{\circ}$ & $<0.001^{\circ}$ \\
\hline \multirow{3}{*}{$\begin{array}{l}\text { To live without } \\
\text { constraints/ } \\
\text { limitations } \\
\text { (mean } \pm \text { SD or \%) }\end{array}$} & & & & & & & & & \\
\hline & No & & 39.6 & & & 0 & $5 \pm 2.4$ & $13.2 \pm 11.4$ & \\
\hline & p-value & & $<0.001^{\circ}$ & & & $<0.001^{*}$ & $<0.001^{\circ}$ & $<0.001^{\circ}$ & 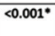 \\
\hline \multirow{3}{*}{$\begin{array}{l}\text { For an effective } \\
\text { treatment } \\
\text { (mean } \pm \text { SD or } \% \text { ) }\end{array}$} & Ye & & & & & & & & .0 \\
\hline & No & $43.6 \pm 13.0$ & 40. & $51.5 \%$ & $1 \%$ & 2.0 & $5 \pm 2.4$ & $13.0 \pm 11.5$ & $4.5 \pm 4.0$ \\
\hline & p-value & & $<0.001^{\circ}$ & $<0.00$ & 156 & $<0.001^{*}$ & $<0.001^{\circ}$ & $<0.001^{*}$ & $<0.001^{\circ}$ \\
\hline \multirow{3}{*}{$\begin{array}{l}\text { To improve } \\
\text { mobility } \\
\text { (mean } \pm \text { SD or \%) }\end{array}$} & res & & & & & & & & $7 \pm 4.1$ \\
\hline & No & 43. & $38.6 \%$ & 5.79 & $67.3 \%$ & 0 & 4 & 1.5 & $4.6 \pm 4.0$ \\
\hline & p-value & 0.753 & $<0.001^{*}$ & 0.240 & 0.508 & $0.001^{\circ}$ & $<0.001^{\circ}$ & $<0.001^{*}$ & $0.001^{\circ}$ \\
\hline \multirow{3}{*}{$\begin{array}{l}\text { To exercise } \\
\text { (mean } \pm \text { SD or } \% \text { ) }\end{array}$} & & 4 & & & & & & & $6 \pm 4.0$ \\
\hline & No & $6 \pm 12.8$ & 39.19 & $51.6 \%$ & $67.8 \%$ & $5.4 \pm 2.0$ & $7.6 \pm 2.4$ & $13.6 \pm 11.7$ & $4.6 \pm 4.0$ \\
\hline & p-ve & 0.059 & $<0.001^{\circ}$ & 362 & 0.0 & 0.0 & $<0.001^{\circ}$ & $<0.0011^{\circ}$ & $<0.00$ \\
\hline
\end{tabular}

explored through mean and contingency analysis and significance was confirmed by Mann-Whitney and Kruskal-Wallis tests.

Results: 2846 axSpA patients participated in EMAS: mean age was 43.9 \pm 12.3 years, $61.3 \%$ were female and $48.1 \%$ university-educated. Mean disease duration was 17.2 \pm 12.4 years, disease activity (BASDAI) $5.5 \pm 2.0$

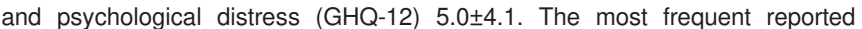
fears were fear of disease progression (32.9\%), suffering pain $(30.5 \%)$, and loss of mobility (30.0\%). Accordingly, the most frequent hopes were to halt disease progression (32.5\%), eliminate pain $(30.7 \%)$, and access effective treatment $(23.3 \%)$. Female patients and those with lower educational level more frequently expressed disease-related fears, while married patients less frequently reported fears. Patients with poorer disease outcomes and higher psychological distress more frequently reported disease-related fears.

Conclusion: Higher physical and psychological burden was significantly associated with expressing fears relating to axSpA. Defining the concerns that are important for patients needs to be considered in order to improve patient-physician communication and shared decision-making with regard to treatment options and goals.

Acknowledgement: EMAS was funded by Novartis Pharma AG

Disclosure of Interests: Marco Garrido-Cumbrera Consultant for: Honoraria from Novartis as steering committe of this survey, Laure Gossec Grant research support from: AbbVie, BMS, Celgene, Janssen, Lilly, MSD, Novartis-Sandoz, Pfizer, Sanofi, and UCB, Consultant for: AbbVie, Biogen BMS, Celgene, Janssen, Lilly, MSD, Nordic Pharma, Novartis-Sandoz, Pfizer, Roche, Sanofi, and UCB, Consultant for: L Gossec has received honoraria from Celgene as investigator for this study, Denis Poddubnyy Grant/research support from: AbbVie, Merck Sharp \& Dohme, Novartis Consultant for: AbbVie, Bristol-Myers Squibb, Janssen, Merck Sharp \& Dohme, Novartis, Pfizer, UCB Pharma, Speakers bureau: AbbVie, BristolMyers Squibb, Janssen, Merck Sharp \& Dohme, Novartis, Pfizer, Roche UCB Pharma, Souzi Makri: None declared, Victoria Navarro-Compán: None declared, Christine Bundy Consultant for: Honoraria from Novartis as steering committe of this survey, Carlos Delgado Domínguez Consultant for: Honoraria from Novartis as steering committe of this survey, Olta Braçe: None declared, Sergio Sanz-Gómez: None declared, Raj Mahapatra Consultant for: Honoraria from Novartis as steering committe of this survey

DOI: 10.1136/annrheumdis-2019-eular.7340

\section{SAT0329 IMPACT OF AXIAL SPONDYOARTHRITIS (AXSPA) ON SOCIAL AND FAMILY LIFE: RESULTS OF THE EMAS SURVEY OF 638 PATIENTS IN 2018}

${ }^{1,2}$ Laure Gossec, Pascal Claudepierre ${ }^{3}$, René-Marc Flipo ${ }^{4,5},{ }^{6,7}$ Marco GarridoCumbrera ${ }^{8}$, Emilie Desfleurs ${ }^{9}$, Francoise Alliot Launois ${ }^{10}$, Laurent Grange ${ }^{11,12}$ ${ }^{1}$ Sorbone University, Paris, France; ${ }^{2}$ La Pitié-Sapêtrière University Hospital, Rheumatology, Paris, France; ${ }^{3}$ Henri Mondor University Hospital, Rheumatology, Créteil, France; ${ }^{4}$ Lille University, Lille, France; ${ }^{5}$ Roger Salengro University Hospital, Rheumatology, Lille, France; ${ }^{6}$ Universidad de Sevilla, Sevilla, Spain; ${ }^{7}$ Health and Territory Research (HTR), Sevilla, Spain; ${ }^{8}$ Spanish Federation of Spondyloarthritis Associations (CEADE), Madrid, Spain; ${ }^{9}$ Novartis Pharma, Medical Affairs, Rueil Malmaison, France; ${ }^{10}$ Association Française de Lutte Antirhumatismale A.F.L.A.R, Vice-President, Paris, France; ${ }^{11}$ Grenoble Alpes University Hospital, Rheumatology, Echirolles, France; ${ }^{12}$ Association Française de Lutte Antirhumatismale A.F.L.A.R, President, Paris, France

Background: Axial Spondyloarthritis (axSpA) has an impact on daily life, but data in the biologics era are scarce.

Objectives: To assess the patient-reported impact of axSpA on social and family life.

Methods: Between December 2017 and February 2018, patients followed for axSpA by their rheumatologists or affiliated to the French patients association AFLAR, and self-reporting axSpA, participated in the European Map of Axial Spondyloarthritis (EMAS) cross-sectional patient survey in France1. Socio-demographics and disease characteristics were collected and the impact of axSpA on personal life was evaluated through a questionnaire established by an international committee on social interactions (better/worse), frequency of social activities (less or more frequent), patient fears and the impact of flares on 10 aspects of daily life evaluated as no/low to moderate/severe. No imputation of missing data was performed and the analyses were descriptive.

Results: Data from 638 persons, mean age $41.5 \pm 11.1$ years, $77 \%$ women, mean disease duration $6.9 \pm 8.2$ years, $19.1 \%$ on biologics, were analyzed. The disease (axSpA) was often active (mean BASDAl: 5.9 $\pm 1.7)$. Social interactions were reported as worse or much worse since axSpA: with friends (43\%), work colleagues $(39 \%)$, spouse $(35 \%)$ and family (31\%). AxSpA had also an impact on the frequency of social and sport activities, which were «much less frequent than before» for spor $(52 \%)$, travels $(38 \%)$, sexual intercourse $(31 \%)$ and cultural outings $(29 \%)$. A moderate to severe impact of disease flares was reported on walking in the street $(53 \%)$, intimate relations $(49 \%)$ and personal hygiene $(35 \%)$. Regarding fears linked to the disease, $71 \%$ of participants feared being unable to do their daily tasks and loosing autonomy and $42 \%$ feared social isolation.

Conclusion: More than half of patients with axSpA in France described a negative impact of axSpA on their family and social life, in a context of fears for the future. These data are important to take into account for shared decision-making.

\section{REFERENCE}

[1] Gossec L, et al. Diagnostic Delay and Associated Factors in Axial Spondyloarthritis across Europe. Results from the European Map of Axial Spondyloarthritis Survey. Arthritis Rheumatol. 2018 Sep;70 Suppl 9:688 
Acknowledgement: Survey supported by Novartis

Disclosure of Interests: Laure Gossec Grant/research support from: AbbVie, BMS, Celgene, Janssen, Lilly, MSD, Novartis-Sandoz, Pfizer, Sanofi, and UCB, Consultant for: AbbVie, Biogen, BMS, Celgene, Janssen, Lilly, MSD, Nordic Pharma, Novartis-Sandoz, Pfizer, Roche, Sanofi, and UCB Consultant for: L Gossec has received honoraria from Celgene as investigator for this study, Pascal Claudepierre Consultant for: Honoraria from Novartis as steering committe of this survey, René-Marc Flipo Consultant for: Honoraria from Novartis as steering committe of this survey, Marco Garrido-Cumbrera Consultant for: Honoraria from Novartis as steering committe of this survey, Emilie Desfleurs Employee of: Employee of Novartis Pharma, Francoise Alliot Launois: None declared, LAURENT GRANGE Consultant for: Laurent Grange has received honoraria from Amgen, Lilly and UCB and research support from Lilly, Amgen, UCB, Expanscience, Mylan, Roche diagnostics and TEVA

DOI: 10.1136/annrheumdis-2019-eular.2741

\section{SAT0330 VALUE OF DIAPHRAGMATIC ASSESSMENT IN RELATION TO PULMONARY FUNCTIONS AND DISEASE ACTIVITY IN AXIAL SPONDYLOARTHROPATHIES: PRELIMINARY REPORT}

Seçilay Güneş ${ }^{1}$, Aysun Genç ${ }^{1}$, İsmihan Sunar ${ }^{2}$, Sevgi Esra Özdemir ${ }^{1}$, Derya Gökmen ${ }^{3}$, Şebnem Ataman ${ }^{2}$, Yesim Kurtais Aytür ${ }^{1} .{ }^{1}$ Ankara University School of Medicine, Physical Medicine and Rehabilitation, Ankara, Turkey, ${ }^{2}$ Ankara University School of Medicine, Physical Medicine and Rehabilitation,

Rheumatology, Ankara, Turkey; ${ }^{3}$ Ankara University School of Medicine, Biostatistics, Ankara, Turkey

Background: Axial Spondyloarthropathies (SpA) are chronic, systemic, inflammatory diseases which affect the axial skeleton, limit chest mobility and cause serious impairments in pulmonary functions.

Objectives: In this cross-sectional study, as a new approach; diaphragm thickness is assessed by ultrasound in patients with axial SpA to determine possible relationships with pulmonary functions and disease activity. Methods: 49 axial SpA patients enrolled in the study were assessed by Bath Ankylosing Spondylitis Disease Activity Index (BASDAI), Bath Ankylosing Spondylitis Functional Index (BASFI), Bath Ankylosing Spondylitis Metrology index (BASMI), Erythrocyte Sedimentation Rate (ESR), serum C-Reactive Protein levels (CRP) and chest expansion (cm). 15 patients with lung diseases other than axial SpA pulmonary involvement, neuromuscular diseases, scoliosis and congenital chest deformity were excluded. Dynamic pulmonary function tests (PFT) and 6 min walk (6MW) tests were done and physical activity levels were evaluated by short form International Physical Activity Questionnaire (IPAQ). Diaphragm thickness was measured at end expiration ( $\mathrm{dtFRC}$ ) and deep inspiration (total lung capacity (dtTLC)). Thickness ratio (dtr: dtTLC/dtFRC) and thickness change (dtc: dtTLC-dtFRC) were calculated.

Results: The descriptive data of the patients are presented in Table 1. Patients had a moderate disease activity and all the patients were category 1 (inactivity) according to IPAQ. Mean value of dtr and PFT seem to be within normal range according to population studies and dtr was significantly correlated with dynamic pulmonary function tests, yet negatively correlated with ESR (r: -0.466, p: 0.006). There was insignificant negative correlation with age, disease duration, BASDAI, BASFI, and BASMI.

Conclusion: To the best of our knowledge, this is the first study evaluating the relation between diaphragm thickness and pulmonary functions

Table 1. Baseline descriptive data characteristics of patients

\begin{tabular}{|c|c|}
\hline $\operatorname{Age}^{a}(y)$ & $46 \pm 10.7$ \\
\hline Female $(n, \%)$ & $26(76.5)$ \\
\hline Male (n,\%) & $8(23.5)$ \\
\hline Disease duration- month ${ }^{b}$ & $\begin{array}{l}60(3-300) \\
\text { Female Male }\end{array}$ \\
\hline $\mathrm{dtFRC}^{\mathrm{a}}(\mathrm{cm})$ & $0.17 \pm 0.40 .18 \pm 0.3$ \\
\hline $\mathrm{dtTLC}^{\mathrm{a}}(\mathrm{cm})$ & $0.34 \pm 0.90 .43 \pm 011$ \\
\hline$d t r^{a}$ & $1.9 \pm 0.32 .42 \pm 0.35$ \\
\hline BASFI ${ }^{b}$ & $4.7(0-8.5)$ \\
\hline BASMI $^{\mathrm{b}}$ & $1(0-9)$ \\
\hline BASDAl $^{\mathrm{b}}$ & $4.5(0.4-8.4)$ \\
\hline MASES $^{b}$ & $3.5(0-13)$ \\
\hline $6 \mathrm{MWT}^{\mathrm{a}}(\mathrm{m})$ & $438 \pm 105$ \\
\hline VCMax $^{a}$ & $3.2 \pm 0.8(95.09 \% \mathrm{~N})$ \\
\hline $\mathrm{FEV} 1^{\mathrm{a}}$ & $2.5 \pm 0.6(93.6 \% \mathrm{~N})$ \\
\hline $\mathrm{PEF}^{\mathrm{a}}$ & $6.0 \pm 1.6(87.4 \% \mathrm{~N})$ \\
\hline
\end{tabular}

with disease activity. Even though, there was no limitation in PFT and expected values were obtained in $\mathrm{dtr}$, the negative correlation with ESR makes us think about the possible effect of disease activity on dtr. With these preliminary results, it is early to conclude, but dtr assessment may be complementary to PFT and early measures to improve diaphragm function with specific exercises should be implemented in patients with axial SpA.

\section{REFERENCE}

[1] Carrillo-Esper R, Pérez-Calatayud ÁA, Arch-Tirado E, Díaz-Carrillo MA Garrido-Aguirre E4, Tapia-Velazco R, Peña-Pérez CA, Espinoza-de Los Monteros I, Meza-Márquez JM, Flores-Rivera OI, Zepeda-Mendoza AD, de la Torre-León T. Standardization of Sonographic Diaphragm Thickness Evaluations in Healthy Volunteers Respir Care 2016;61(7):920-4

a: mean \pm SD, b: median (min-max), MASES: Maastrich Ankylosing Spondylitis Enthesitis Score, VC: Vital Capacity, FEV: Forced Expiratory Volume, PEF: Peak Expiratory Flow, N: Normal

Disclosure of Interests: None declared

DOI: 10.1136/annrheumdis-2019-eular.6081

\section{SAT0331 THE DIAGNOSTIC UTILITY OF THE DETECTION OF EROSIONS IN SACROILIAC JOINTS IN PATIENTS WITH EARLY SPONDYLOARTHRITIS}

Dorra Ben Nessib ${ }^{1}$, Wafa Hamdi', Kaouther Maatallah ${ }^{1}$, Hend Riahi $^{2}$, Dhia Kaffel ${ }^{1}$, Hanene Ferjani ${ }^{1}$, Med Montacer Kchir'. ${ }^{1}$ Kassab Institute, Rheumatology, Manouba, Tunisia; ${ }^{2}$ Kassab Institute, Radiology, Manouba, Tunisia

Background: In the light of new therapeutic strategies, it has become essential to detect spondyloarthritis (SpA) in its earliest stages in order to initiate treatment as early as possible. Magnetic resonance imaging (MRI), with its ability to detect active lesions, is usually considered as a key tool for early recognition of sacroilitis. However, a growing number of studies reported the lack of specificity of bone marrow edema (BME) leading sometimes to a false "positive MRl" of sacroiliac joints (SIJ). In addition, many recent studies have pointed out the utility of detecting structural lesions, especially erosions, reported as the earliest structural change on SIJ in the course of sacroiliitis.

Objectives: We aimed to assess the reliability of early recognition of erosions in patients with suspected SpA.

Methods: Consecutive patients, aged 16 and over, consulting from February 2014 to February 2017 for symptoms suggestive of SpA (inflammatory back pain, enthesitis or dactylitis...) were enrolled in this cohort. They were referred for computed tomography (CT) and MRI of the SIJ. The CT and MR images were reviewed for the presence of erosions by 2 musculoskeletal radiologists blinded to clinical findings. After a follow-up of 2 years, 2 experienced rheumatologists confirmed or excluded the diagnosis of SpA. Diagnostic utility of erosions for diagnosis of SpA was determined by calculating sensitivity, specificity, positive and negative likelihood ratio with final clinical diagnosis made by rheumatologists as golden standard.

Results: Fifty-four patients were included, 13 men and 41 women. The mean age was 39 years [17-71]. The mean duration of symptoms was 75 months (6 years). Cervical, thoracic, lumbar and buttock pain were noted respectively in $46.3 \%, 37 \%, 87 \%$, and $57.4 \%$ of the studied patients. Morning stiffness was noted in $55.5 \%$ of patients. The prevalence of HLA-B27 was $23.4 \%$. After a follow-up of 2 years, the referring rheumatologists made a diagnosis of SpA in $77.8 \%$ of patients, whereas SpA was excluded in $22.2 \%$. Among the 42 patients classified as having a confirmed SpA, erosions were detected on SIJ by CT in $64.3 \%(n=27)$ and by MRI in $(n=18) 42.85 \%$ of patients. Among the 12 patients in whom Spa was excluded, erosions were detected on SIJ by CT in $25 \%$ $(n=3)$ of patients and were not detected by MRI in any patient. Sensitivity, specificity, positive and negative likelihood ratio of erosions detected by CT were respectively estimated at $64.3 \%, 75 \%, 90 \%$ and $37.5 \%$. Those of erosions detected by MRI were estimated at $42.9 \%, 100 \%$, $100 \%, \quad 33.33 \%$. A statistically significant association was observed between erosions and rheumatologists' diagnosis of SpA $(p=0.05$ for CT and $\mathrm{p}=0.012$ for $\mathrm{MRI}$ ). The likehood ratio was estimated respectively for $\mathrm{CT}$ and MRI at 3.8 and 7.6 .

Conclusion: In our study, detection of erosions showed a high specificity for recognition of sacroilitis, especially when detected by MRI. This study highlights the utility of structural SIJ lesions, particularly erosions, to reduce the number of false positives.

Disclosure of Interests: None declared

DOI: 10.1136/annrheumdis-2019-eular.6453 